\title{
EFFECT OF ACCOUNTING INFORMATION AND NON-ACCOUNTING INFORMATION ON UNDER-PRICING IPO AND FIRM VALUE: A STUDY OF COMPANIES LISTED ON THE INDONESIA STOCK EXCHANGE DURING PERIOD OF 2008-2014
}

\author{
Budianto K.* \\ Doctoral Program of Business Administration, Faculty of Administrative Sciences, \\ University of Brawijaya, Malang, Indonesia \\ Suhadak, Professor \\ Rahayu S.M., Dzulkirom A.R.M., Lecturers \\ Faculty of Administrative Sciences, University of Brawijaya, Malang, Indonesia \\ *E-mail: ha kukuhbudianto@yahoo.com
}

\begin{abstract}
Underpricing phenomenon occurs in stock markets in the world, including in the UK, in Australia, in the United States, in South Africa, in Korea in, China, in Malaysia and in Indonesia. Previous studies that discussed the effect of Accounting Information and NonAccounting Information variables on Underpricing IPO and Corporate Value gave different results, the effect of Underpricing IPO variables on long-term corporate value experienced a lot of underperformance. This study aims to obtain empirical evidence on the effect of Accounting Information and Non-Accounting Information on Underpricing IPO and Firm Value, for companies listed on the Indonesia Stock Exchange in 2008 - 2014. The population of this study is all companies that conduct Initial Public Offering (IPO) and listings on the Indonesia Stock Exchange from 2008 to 2014 as many as 105 companies. The population that meets the criteria to be sampled is 70 companies. The research method used in this study is Warp-PLS. The results showed that the effect of (1) Accounting Information on Underpricing's IPO was not significant (2) Non-Accounting Information on Underpricing's IPO was negative and significant (3) Accounting Information on Firm Value was positive and significant (4) Non Accounting Information on Firm Value is not significant (5) Underpricing's IPO information on Firm Value is negative and significant.
\end{abstract}

\section{KEY WORDS}

Accounting information, non accounting information, underpricing, firm value.

The Underpricing phenomenon occurs in many stock markets throughout the world. Previous research that discussed the effect of Accounting Information variables on Underpricing's IPO still gave different results, Rasheed and Datta (1997), Melnik, et al (2003), Daljono (2000), Hasan, et al (2013), had a significant negative effect while research by Daugherty and Thadavillil (2012), Martani (2012), Razafindrambinina, et al (2013), Agathee, et al (2012), Durukan, et al (2002), Thanyawee (2012), Dominique and Kwan (2013) have no effect significant.

The effect of the variable Non Accounting Information on Underpricing's IPO results is also different, the research of Zahn, et al (2008), Chisty (2012), Mohamad and Annuar (1997), Martani (2012), and Thanyawee (2012) have no significant effect. The study of Dominique and Kwan (2013), Daugherty and Thadavillil (2012) and Agathee, et al (2012) have a significant positive effect, Brau and Carpenter (2012), Kim, et al (1993), Caster and Manaster (1990), How , et al (1995), Beatty (1989) and Salim \& Randy (2013) the results have a significant negative effect. The effect of Underpricing IPO variables on Corporate Value, assessing the long-term performance of companies on stocks that experience Underpricing gives almost the same results, Kooli and Jean (2001), Bachmann, (2004), Jay ritter (1991), Durukan, et al ( 2002), Bessler and Stefan (2007), Seal and Jasbir (2012) and 
Schlag and Anja (2000) long-term performance underperformance, while Albert Corhay (2002) and Xia (2012) studies have experienced abnormal returns.

De Lorenzo and Fabrizio (2001), explained that almost all of the previous studies of Underpricing IPOs were the result of asymmetry of information on perpetrators of Initial Public Offering (IPO), namely Underwriters, Issuers and Investors. Signaling theory Ross (1977), that management has better information about its company and provides information to investors hoping that the company's stock price increases. Good signals are given by the company for the company's performance for the future, but past financial performance is not good, the market will not believe it. Wolk, et al (2001).

Empirically in this study, is the development of previous research, discussing and developing the main concepts, explaining the Accounting Information Variables and Non Accounting Information Variables, their effects on Underpricing IPO and Corporate Value.

\section{LITERATURE REVIEW}

Accounting Information, Bushman, at al. (2001), is a product of the company's accounting system and reporting system for external measures and openly discloses quantitative data regarding the financial position and performance of public companies. The balance sheet, income statement and audited statement of cash flows are the basis of company-specific information available to Investors and regulators. The Accounting Information variable in this study uses 4 indicators, namely: Return On Assets (ROA), Return on Equity (ROE), Debt to Equity Ratio (DER) and Earning per Share (EPS).

Non Accounting Information, is company information in addition to the quantitative values contained in financial statements. Non-Accounting information includes Underwriters Reputation, Auditor Reputation, inflation rate, currency exchange rates, interest rates, macroeconomics, government policies and government ownership (BUMN). In this study Non Accounting Information uses the Reputation of Underwriters and Reputation of Auditors.

Underpricing, Beatty (1989) IPO, Underpricing phenomenon has a different impact between issuers and Investors, companies are disadvantaged by Underpricing conditions because the funds obtained from go-public cannot be maximum, if there is overpricing Investors will be harmed, because they do not accept Initial Return . Initial Return is the profit obtained by shareholders on the difference in the price of shares purchased in the primary market with the selling price of shares on the first day on the secondary market. Underpricing is used to describe the difference between the price of offering shares in the primary market and the price of shares in the secondary market on the first day (Beatty, 1989). De Lorenzo and Fabrizio (2001), almost all previous studies have explained the occurrence of underpricing as a result of information asymmetry between issuers, underwriters, and investors. For issuers, Underpricing can be detrimental because the funds obtained cannot be maximized. Underpricing can also be used as a marketing strategy to increase interest Investors invest in shares at the Initial Public Offering (IPO) by giving a high Initial Return. Kim and Shin (2001), the possibility of Underpricing is due to the intentions of the Underwriter to set the bid price below the secondary market price, the aim of minimizing the loss that the underwriter must bear if the shares are not sold.

Corporate Value, Gitman (2006), is the actual value per share that will be received if the company's assets are sold in accordance with the stock price. If a high corporate value means increasing the prosperity of shareholders. Firm value is also defined as Investor's perception of the company, which shows the price to be paid by the Investor. High stock market prices also make high corporate value and vice versa. The Firm value in this study is proxied by Book Value (BV), Price to Book Value (PBV), Closing Price, Price Earning Ratio (PER) and Tobin's $Q$ which will be described as below.

The research hypothesis is as follows:

$\mathrm{H} 1$ : Accounting Information has an effect on Underpricing's IPO;

$\mathrm{H} 2$ : Non Accounting Information has an effect on Underpricing's IPO;

H3: Accounting Information has an effect on Firm Value;

H4: Non Accounting Information has an effect on Firm Value; 
H5: Underpricing IPO has an effect on Firm Value.

\section{RESEARCH DATA AND OPERATIONAL DEFINITIONS}

This type of research data is timeseries secondary data which is data collected in a time sequence. This research data was obtained from the Indonesia Stock Exchange (IDX) and published through the Indonesia Capital Market Directory (ICMD) in 2008-2014 in the form of financial statements of companies whose shares experienced underpricing. The population in this study were all companies that made Initial Public Offering (IPO) on the Indonesia Stock Exchange for the period 2008-2014. The population of this study was taken from all companies that conducted Initial Public Offering (IPO) and experienced underpricing on the Indonesia Stock Exchange from 2008 to 2014 as many as 105 companies. Samples were taken from populations that met the criteria after deducting companies with overpricing of 18 companies, minus the type of banking and financing companies of 8 companies, minus companies with incomplete 9 companies, so that the research sample amounted to 70 companies. Sources of research data and formulas are grouped based on the research variables as follows.

Figure 1 - Research Variables, indicators and formulas

\begin{tabular}{|c|c|c|c|c|}
\hline No & Variable & Indicator & Data Source & Formula \\
\hline & 1 & 2 & 3 & \\
\hline 1 & $\begin{array}{l}\text { Accounting } \\
\text { Information }\end{array}$ & $\begin{array}{c}\text { Return on Asset (ROA) } \\
\text { Return on Equity (ROE) } \\
\text { Debt to Equity Ratio (DER) } \\
\text { Earning per Share (EPS) }\end{array}$ & ICMD & $\begin{array}{c}\text { ROA }=\frac{\text { Earning After Tax }}{\text { Total Assets }} \\
\text { ROE }=\frac{\text { Earning After Tax }}{\text { Total Equity }} \\
\text { DER }=\text { Total Debt } \\
\text { Tot Share Equity } \\
\text { EPS }=\text { Earning After Tax } \\
\sum \text { Saham Beredar }\end{array}$ \\
\hline 2 & Non-Accounting Information & $\begin{array}{c}\text { Underwriter Reputation (RU) } \\
\text { Auditor Reputation (RA) }\end{array}$ & $\begin{array}{c}\text { Blomberg } \\
\text { Directory KAP }\end{array}$ & $\begin{array}{l}\text { Dummy Variable } \\
\text { Dummy Variable }\end{array}$ \\
\hline 3 & IPO Underpricing & Initial Return & www.idx.co.id & $\frac{\mathrm{CP} \mathrm{H} 1-\text { Harga IPO }}{\text { Harga IPO }}$ \\
\hline 4 & Firm Value & $\begin{array}{c}\text { Book Value (BV) } \\
\text { Price to Book } \\
\text { Value (PBV) } \\
\text { Closing Price (CP) } \\
\text { Price to Earning Ratio (PER) } \\
\text { Tobin's Q }\end{array}$ & ICMD & $\begin{array}{c}\text { BV }=\text { Total Equity } \\
\text { Out standing Share } \\
\text { PBV }=\text { Current Price } \\
\text { Book Value } \\
\mathrm{CP}=\text { Log Closing Price } \\
\mathrm{PER}=\frac{\text { Current Price }}{\text { EPS }} \\
(E M D+D) /(E B V+D)\end{array}$ \\
\hline
\end{tabular}

\section{METHODS OF RESEARCH}

Data analysis methods used include financial ratio analysis, descriptive statistical analysis and inferential statistical analysis. Inferential statistical analysis of this study uses Warp-PLS analysis. Warp-PLS is used based on the fact that the research concept model is a multi-influential and tiered influence. In addition, the variables analyzed in this study are latent with the indicator model reflective and foramative. The effect model between variables in this study is described by the system of equations as follows:

$$
\begin{gathered}
Y_{1}=a_{1}+b_{1} X_{1}+b_{2} X_{2}+e_{1} \\
Y_{2}=a_{2}+b_{3} X_{1}+b_{4} X_{2}+b_{5} Y_{1}+e_{2}
\end{gathered}
$$


Where: $X_{1}$ - Accounting Information; $X_{2}$ - Non-Accounting Information; $Y_{1}$ - IPO Underpricing; $\mathrm{Y}_{2}$ - Firm Value.

Exploration Indicator Loading and Weights, The weight value of the factor (weight indicator) describes the strength of the indicator (dimension) as a measure of the variable. Dimensions (indicators) with a large value of weight factors indicate the dimensions (indicators) have a strong ability to reflect variables. Dimensions (indicators) with the weight value of the biggest factor is the most powerful (dominant) dimension as a measure of the variable concerned. A positive or negative sign indicates the direction, as found in the path coefficient (regression).

The results of the analysis of the weight of the factor (indicator weight) in full are presented in the following table.

Table 1 - Indicator Loading for Non Accounting Information Variables

\begin{tabular}{|c|c|c|c|c|}
\hline No & Indicator & Loading & p value & Remarks \\
\hline \multicolumn{4}{|c|}{ Non Accounting Information Variables } \\
\hline 1 & Underwriter Reputation (RU) & 0.836 & $<0.001$ & Strong \\
\hline 2 & Auditor Reputation (RA) & 0.836 & $<0.001$ & Strong \\
\hline
\end{tabular}

The RU and RA indicators in the table above are equally strong, RU and RA have balanced strength reflecting Non Accounting Information.

Table 2 - Weight Indicator for Variable Accounting Information and Firm Value

\begin{tabular}{|c|c|c|c|c|}
\hline No & Indicator & Weight & p value & Remarks \\
\hline \multicolumn{5}{|c|}{ Accounting Information Variables } \\
\hline 1 & ROA & 0.387 & $<0.001$ & - \\
\hline 2 & ROE & 0.360 & $<0.001$ & Strongest \\
\hline 3 & EPS & 0.415 & $<0.001$ & - \\
\hline \multicolumn{5}{|c|}{ Firm Value Variables } \\
\hline 1 & BV & 0.377 & $<0.001$ & Strongest \\
\hline 2 & PBV & 0.342 & 0.001 & $<0.001$ \\
\hline 3
\end{tabular}

EPS indicator is the strongest indicator in forming Accounting Information variables, then ROA and ROE, but the strength is relatively balanced, because the difference in weight values is only the second digit behind comma. CP indicators are the strongest indicators in forming Corporate Value variables, followed by BV and PBV.

\section{RESULTS AND DISCUSSION}

Hypothesis testing is done using Warp-PLS analysis, the results of hypothesis testing can be seen in the following figure.

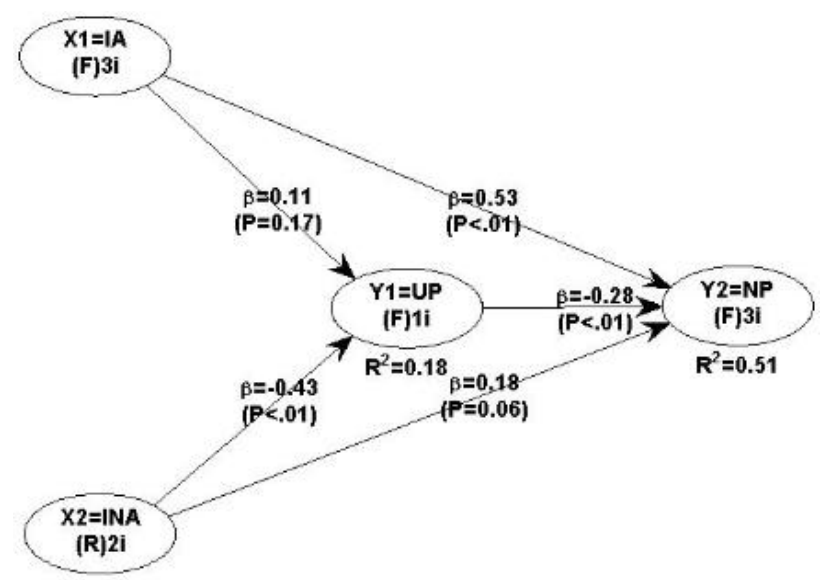

Figure 1 - Hypothesis Testing Results 
Table 3 - The results of hypothesis testing

\begin{tabular}{|c|c|c|c|c|}
\hline \multirow{2}{*}{ No } & \multicolumn{2}{|c|}{ Effect between Variables } & \multirow{2}{*}{ Path Coefficient } & \multirow{2}{*}{$p$-value } \\
\cline { 2 - 3 } & Independent Variables & Dependent Variables & $0.110^{\text {ns }}$ & 0.172 \\
\hline 1 & Accounting Information & IPO underpricing & $-0.434^{\star * *}$ & $<0.001$ \\
\hline 2 & Non Accounting Information & IPO underpricing & $0.528^{\star \star *}$ & $<0.001$ \\
\hline 3 & Accounting Information & Firm value & $0.179^{\text {ns }}$ & 0.058 \\
\hline 4 & Non Accounting Information & Firm value & $-0.279^{\star *}$ & 0.006 \\
\hline 5 & IPO Underpricing & Firm value & \\
\hline
\end{tabular}

Notes: ${ }^{* * *}=$ significant on $\alpha 0.01$ (highly significant); ${ }^{* *}=$ significant on $\alpha 0.05$ (significant); $n s=$ not significant.

The results of the analysis of the effect of Accounting Information on Underpricing IPO, path coefficient value $=0.110$ and $p$-value $=0.172$ results are not significant. This result illustrates that the good and bad of Accounting Information will not determine the Underpricing IPO. The theory of information asymmetry, Baron (1982), explains that differences in information held by issuers, underwriters, and investors result in underpricing. This study is consistent with the research of Martani, et al (2012), and supports the research of Razafindrambinina, et al (2013).

The results of the analysis of the effect of Non Accounting Information on Underpricing IPO, path coefficient value $=-0.434$ and $p$-value $<0.001$ results are significant. The negative path coefficient shows that the better Non Accounting Information, the lower Underpricing IPO. This study is consistent with the study of Carter and Manaster (1990), consistent with the research of Brau and Carpenter (2012). However this study does not support the research of Annuar (1997) and Martani, et al (2012) whose results are not significant.

The results of the analysis of the effect of Accounting Information on Firm Value, path coefficient value $=0.528$ and $p$-value $<0.001$ the result is significant. The path coefficient is positive, indicating the better information on accounting. The higher the Firm Values. This study is consistent with Blessing's research (2015).

The results of the analysis of the effect of Non Accounting Information on Firm Value, path coefficient value $=0.179$ and $p$-value $=0.058$ the results are not significant. These results indicate the good or bad of Non Accounting Information does not determine the high or low Firm Values. This study supports the results of the study of Martani, et al (2012), but does not support the research of Razafindrambinina, et al (2013).

The results of the analysis of the effect of Underpricing IPO Information on Firm Value path coefficient value $=-0,279$ and $p$-value $=0.006$ the results are significant. The path coefficient is negative, indicating that the higher the Underpricing IPO, the lower the value of the Company. This study proves the theory of Long-run Underpricing, Ritter (1991) which states that Underpricing IPO, in the long-term performance underperformance and abnormal returns occur. This study also proves empirically the Overreaction Theory, which states that the initial share price set by the underwriter is appropriate, and the positive Initial Return that arises is a result of irrational investor overreaction, Ritter, et al (1991).

\section{CONCLUSION}

The conclusions of the results of this study using Warp-PLS are: 1). The effect of Accounting Information on Underpricing's IPO is insignificant. 2). The effect of Non Accounting Information on Underpricing's IPO is negative and significant. 3). The effect of Accounting Information on Firm Values is positive and significant. 4). The effect of Non Accounting Information on Firm Values is not significant. 5). The effect of Underpricing's IPO Information on Firm Values is negative and significant.

\section{REFERENCES}

1. Agathee, Ushad Subadar, Chris Brooksb dan Raja Vinesh Sannasseea.(2012). Hot and cold IPO markets: The case of the Stock Exchange of Mauritius. Journal of Multi Finance Management, 22,168-192. 
2. Aggarwal, Rajesh K. , Laurie Krigmanb, Kent L. Womack.(2002). Strategic IPO underpricing, information momentum, and lockup expiration selling. Journal of Financial Economics,66,105-137.

3. Albert Corhay (2002). The Long Run Performance of Malaysian Initial Public Offerings (IPOs): Value and Growth Effects. Managerial Finance, Volume 28 Number 2.

4. Bachman, Ralph (2004). A Theory of IPO Underpricing, Issue Activity, and Long-Run Underperformance. Nanyang Business School Division of Banking and Finance. Nanyang Avenue, S3-B1A-14 Singapore 639798.

5. Baron, David P. (1982). A Model of the Demand for Investment Banking Advising and Distribution Services for New Issues. The Journal of Finance, Vol. 37, No. 4 (Sep., 1982), pp. 955-976.

6. Beatty, Randolp P.(1989). Investment banking, reputation and the underpricing of initial public offering. Journal of Financial Economics, No. 15, pp.213-232.

7. Bessler and Stefan (2007). The long-run performance of initial public offerings in Germany. Managerial Finance. Vol. 33 No. 6, 2007 pp. 420-441.

8. Blessing, ljeoma Ngozi (2015), Value Relevance of Accounting Information on Share Prices of Listed Firms. Social and Basic Sciences Research Review Volume 3, Issue 10 Pages: 328-344.

9. Brau and Carpenter (2012). SMALL-FIRM UNIQUENESS AND SIGNALING THEORY. Journal of Business, Economics \& Finance, ISSN: 2146 - 7943.

10. Bushman, Robert M. and Abbie J. Smith.(2001).Financial accounting information and corporate governance. Journal of Accounting and Economics, vol. 32.

11. Carter, Richard and Steve Manaster. (1990).Initial Public Offering and Underwriter Reputation.Journal of Finance, Vol. XIV, No 4, September.

12. Chishty, M.R.K., I Hasan and S.D. Smith. (1996). A Note on Underwriter Competition and Initial Public Offerings.Journal of Business Finance and Accounting, 23:5-6, pp.905- 14.

13. Daljono. (2000). Analisis Faktor-Faktor yang Mempengaruhi Initial Return Saham yang Listing di BEJ Tahun 1990 - 1997.Kumpulan Makalah Simposium NasionalAkuntansi III, 556572.

14. Daugherty, Mary Schmid. (2012). Underpricing of IPOs of U.S. Family Controlled Businesses. UST Research Online University of ST. Thomas, Minnesota.

15. De Lorenzo, Massimo and Stefano Fabrizio. Asymetric Information and The Role of Underwriter, The Prospectus and The Analyst in Underpricing of IPO. The Italian Case.

16. Durukan, M. Banu. (2002). The Relationship between IPO return and Factors Influencing IPO performance Case of Istambul Stock Exchange. Manajerial Finance, Vol.28, No.2.

17. Gitman, Lawrence J, 2006. Principles of Managerial Finance, $10^{\text {th }}$ ed., International Editions Financial Series, Boston. USA, Addison-Wesley.

18. Hasan, Hadad (2013). Value Relevance of Accounting Information and IPO Performance in Indonesia. Accounting and Finance Research Vol. 2, No. 1.

19. Kim, J., Krinsky, I., Lee, J. (1993). Motives for going public and underpricing: new findings from Korea. Journal of Business Finance and Accounting, 20 (2), 195-211.

20. Kooli, M., Suret, J.M., (2002). How Cost-Effective are Canadian IPO Markets? Working Paper. Centre for Interuniversity Research and Analysis on Organisations.

21. Kunz and Aggrawal. (1994). "Why IPO are Underpriced: Evidence From Switzerland", Journal of Business and Finance, Vol. 18.

22. Martani Dwi, Ika Leony Sinaga and Akhmad Syahroza.(2012). Analysis on Factors Affecting IPO Underpricing and their Effects on Earnings Persistence. Word Review of Busness Research,Vol. 2. No. 2 pp. 1-15.

23. Melnik (2003), Value-Relevance of Accounting Information and the Predictability of IPO Underpricing. University of Haifa, Israel \& Cass Business School, City University, London.

24. Rasheed, Abdul M.A., Deepak K. Datta. (1997). Determinants of Price Premium: A Study of Initial Public Offerings In The Medical Diagnostic And Devices Industry". Journal of Small Business Management, vol.35 No.4. 
25. Razafindrambinina, Dominique and Tiffany Kwan.(2013). The Influence of Underwriter and Auditor Reputations on IPO Under-pricing, European Journal of Business and Management www.iiste.org ISSN 2222-1905 (Paper) ISSN 2222-2839 (Online) Vol.5, No.2, 2013.

26. Ritter, J. (1991). The Long-run Performance of Initial Public Offerings.Journal of Finance, 46:1, pp.3-27.

27. Ross (1977), The determination of financial structure: the incentive-signalling approach. The Bell Journal of Economics, Vol. 8, No. 1, (Spring, 1977), pp. 23-40.

28. Salim and Randy (2012), Underpricing, board structure, and ownership An empirical examination of Indonesian IPO firms. Managerial Finance Vol. 39 No. 2, 2013 pp. 181200.

29. Seal and Jasbir (2012), Long Run Performance of Initial Public Offerings and Seasoned Equity Offerings in India. Working Paper, W.P. No. FI-13-19.

30. Schlag and Anja (2000), Has There Always Been Underpricing and Long-Run Underperformance? - IPOs in Germany Before World War I. Center for Financial Studies D-60329 Frankfurt.

31. Thanyawee (2012), The effect of an audit firm's brand on security pricing. International Journal of Emerging Markets Vol. 7 No. 4, 2012 pp. 430-442.

32. Wolk, Tearney and Dodd. (2001). Accounting Theory: A Conceptual and Institusional Approach. USA: South Western College Publishing.

33. Xia (2012), Empirical study on initial public offering (IPO) underpricing and long-run performance: Evidence from China's A-share market. African Journal of Business Management Vol. 7(11), pp. 852-861.

34. Zahn (2008), Association between independent audit committee members' humanresource features and underpricing. Journal of Human Resource Costing \& Accounting Vol. 12 No. 3, 2008 pp. 179-212. 